\title{
MANAJEMEN KONFLIK SEKOLAH REGROUPING DI SD NEGERI PUCANGSAWIT SURAKARTA
}

\author{
Suwarto \\ SD Pucangsawit Surakarta \\ suwartodzaki@gmail.com
}

\begin{abstract}
The objectives of the research are to describe: 1) the sources and types of conflict; 2) the conflicts' management; and 3) the supporting and inhibiting factors in conflict management of regrouped school at State Elementary School Pucangsawit Surakarta. The type of the research is qualitative with naturalistic design. The research was undertaken at State Elementary School Pucangsawit Surakarta. The results are 1) the conflict sources at State Elementary School Pucangsawit Surakarta can be classified into two types of sources, namely the teachers and parents. The conflict types emerged at the form of inter-individual conflict among teachers from the regrouped schools, the conflict in school naming, conflict related to professional tasks and teachers' administration, and conflict related to students' administration; 2) the conflict management at State Elementary School Pucangsawit Surakarta were done through planning, organizing, actuating, and controlling. The conflict resolution referring to schools' rivalry is done by applying fair and positive competition; and 3) the supporting factors in conflict management are the government support and schools'stakeholder's awareness. The inhibiting factors cover the self ego that remains existed in some teachers and parents from both of the schools regrouped.
\end{abstract}

Keywords: conflict management, school regrouping, self ego, fair and positive competition

\begin{abstract}
Abstrak. Penelitian ini bertujuan untuk mendeskripsikan: 1) sumber dan jenis konflik; 2) pengelolaan konflik; dan 3) faktor pendukung dan penghambat dalam pengelolaan konflik sekolah paska regrouping di SD Negeri Pucangsawit Surakarta. Jenis penelitian adalah kualitatif dengan desain naturalistik. Penelitian dilakukan di SD Negeri Pucangsawit Surakarta. Penelitian menyimpulkan bahwa: 1) Sumber-sumber konflik di SD Negeri Pucangsawit Kecamatan Jebres Kota Surakarta dapat diklasifikasi ke dalam 2 jenis sumber, yaitu dari guru dan orang tua siswa. Jenis-jenis konflik paska-regrouping SD Negeri Pucangsawit Surakarta Surakarta meliputi konflik antar-individu guru dari kedua sekolah yang digabung, konflik penamaan sekolah, konflik terkait dengan tugas profesional dan administrasi kepegawaian guru, konflik terkait administrasi kesiswaan; 2) Pengelolaan konflik dilakukan melalui perencanaan, pengorganisasian, pelaksanaan, dan pengendalian. Penyelesaian konflik yang berkaitan dengan persaingan antar-sekolah diatasi dengan menerapkan persaingan positif dan adil; dan 3) Faktor pendukung dalam penanganan konflik paska regrouping di SD Negeri Pucangsawit Surakarta adalah adanya dukungan pemerintah dan kesadaran warga sekolah. Faktor penghambat dalam penanganan konflik paska regrouping adalah berupa adanya ego sektoral yang melekat pada guru dan orang tua siswa di kedua sekolah yang diregroup.
\end{abstract}

Kata kunci: manajemen konflik, regrouping sekolah, ego pribadi, persaingan positif dan adil 


\section{Pendahuluan}

Kebijakan pemerintah tentang regrouping sekolah yang tertuang dalam SK Mendagri Nomor 421.2/2501/Bangda/1998 tentang Pedoman Pelaksanaan Penggabungan (Regrouping) Sekolah Dasar bertujuan untuk mengatasi masalah kekurangan tenaga guru, peningkatan mutu, efisiensi biaya bagi perawatan gedung sekolah dan sekolah yang ditinggalkan dimungkinkan penggunaannya untuk rencana pembukaan SMP kecil/SMP kelas jauh atau setara sekolah lanjutan sesuai ketentuan setempat untuk menampung lulusan sekolah dasar. Kebijakan tersebut sudah dilaksanakan di berbagai sekolah yang dianggap layak untuk di-regroup dengan berbagai alasan.

Di satu sisi, kebijakan tersebut memang cukup efisien dalam meningkatkan mutu dan efisiensi pengelolaan pendidikan. Di sisi lain, kebijakan tersebut juga menimbulkan berbagai masalah sosial yang timbul sebagai dampak ikutan dari proses regrouping sekolah tersebut.

Hasil penelitian Kiemas Rizka (2005) menunjukkan bahwa perencanaan sarana dan prasarana pendidikan SDN yang terkena kebijakan regrouping yang tidak digunakan untuk KBM umumnya sudah direncanakan dan dimusyawarahkan terlebih dulu oleh kedua belah pihak (sekolah yang digabungi dengan yang digabung) yang dihadiri oleh kepala sekolah, guru, komite sekolah/BP3 kedua SD serta dihadiri oleh perangkat desa setempat dan Dinas Pendidikan Kulonprogo. Hasil penelitian Yuliana (2004) menunjukkan bahwa regrouping SD Balangan 1 dan SD Sendangrejo mampu berperan dalam meningkatkan efisiensi pendidikan di sekolah dasar. Dijelaskan lebih jauh, nilai indeks efisiensi meningkat dari 1,0 menjadi 2,3 atau meningkat dari 0,43 menjadi 1,0. Efisiensi biaya produksi tiap satuan produk (unit cost) sebesar Rp. 1.587.119,566 dengan peningkatan produktivitas dari 9,75 menjadi 15,59 atau terjadi peningkatan produktivitas sebesar 5,84. Regrouping juga mampu mengatasi kekurangan guru sekolah dasar di kecamatan Minggir dengan sumbangan efektif 6,4\%, dari total kekurangan guru sejumlah 78 orang. Regrouping juga mampu meningkatkan mutu pendidikan melalui perbaikan sarana prasarana pendidikan.

Hasil penelitian Marsono (2003) menunjukkan bahwa regroupng menimbulkan masalah, baik masalah organisasi, kesiswaan, kurikulum (pengajaran), kepegawaian, pembiayaan, hubungan sekolah dengan masyarakat, dan ketatalaksanaan, karena pelaksanaan penggabungan sudah dilakukan, tetapi surat keputusan penggabungan belum terbit.

Penelitian Yuliana, nampaknya lebih memberikan kejelasan terhadap efektifitas dan efisiensi tujuan regrouping, bahkan implikasi terhadap hasil penelitian tersebut dijelaskan bahwa sekalipun kesimpulannya merupakan sebuah indikasi positif bagi pelaksanaan regrouping sekolah, namun demikian kehatihatian dalam mengalisa indikasi regrouping sekolah sangat diperlukan mengingat jumlah penduduk yang kemungkinan besar terus bertambah banyak.

Dari beberapa penelitian yang sudah dilakukan di atas, aspek konflik yang terjadi di sekolah paska regrouping yang menjadi dampak ikutan dari kebijakan tersebut belum tersentuh dan dikaji. Di sisi lain, aspek konflik dalam organisasi sebagai akibat penggabungan dua atau lebih sekolah ke dalam satu wadah pasti tidak dapat dihindarkan. Hal ini dikarenakan bahwa masing-masing sekolah sebelum digabung sudah memiliki karakter dan budaya organisasi yang berbeda. Dengan adanya penggabungan dua budaya dan karakter yang berbeda tentu saja menimbulkan konflik dalam berbagai bentuk. Hal tersebut dikemukakan oleh Denohue (1992) yang menyatakan bahwa "Conflict ... arises when a difference between two or more people necessitates change in at least one person in order for their engagement to continue and develop" (Ghaffar, 2012: 212213).

Konflik yang terjadi paska regrouping sekolah juga terjadi di SD Negeri Pucangsawit 
Kecamatan Jebres Kota Surakarta. Sekolah tersebut merupakan penggabungan dari SD Negeri Kentingan No. 79 Surakarta dengan SD Negeri Pucangsawit No. 119 Surakarta.

Dua sekolah yang memang berada dalam satu kompleks bangunan tersebut digabung menjadi satu sekolah baru dengan nama SD Negeri Pucangsawit. Regrouping kedua sekolah tersebut dilakukan berdasarkan Surat Keputusan Walikota Surakarta Nomor. 421.2/69-A/1/2012 tertanggal 18 Juli 2012.

Konflik yang terjadi semakin meruncing ketika nama yang digunakan untuk sekolah baru adalah SD Negeri Pucangsawit sesuai dengan SK Walikota Surakarta. Konflik tersebut termanifestasikan ke dalam bentuk ketidaksukaan antara satu sama lain dan perasaan negatif diantara mereka. Konflik semacam ini oleh Campbell, Carbally, dan Nustrand dikategorikan sebagai bentuk affective conflict, yaitu "a condition in which group members have interpersonal clashes characterized by anger, frustration, and other negative feelings" (Ghaffar, 2012: 215).

Konflik yang berkepanjangan di sekolah tersebut tentu saja tidak kondusif untuk kondisi pembelajaran. Iklim sekolah menjadi tidak kondusif untuk pembelajaran sebagai akibat terjadinya konflik di sekolah tersebut. Para guru dari kedua sekolah pun belum bersedia menempati satu ruangan yang sama. Guru yang berasal dari SD Negeri Kentingan tetap menempati ruang guru di SD Negeri Kentingan, sedangkan guru yang berasal dari SD Negeri Pucangsawit tetap menempati ruangan guru di SD Negeri Pucangsawit.

Konflik yang terjadi di sekolah tersebut paska kebijakan regrouping harus dikelola dan diselesaikan dengan baik. Konflik yang terjadi tersebut pada dasarnya merupakan bagian dari kehidupan sekolah. Hal ini dikemukakan oleh Albert (2001) sebagaimana dikutip oleh Akinnubi, Oyeniran, Fashiku, dan Durosaro (2012: 170) yang menyatakan bahwa "Conflict is part of a school because teachers have varying ideas about issues, they have different backgrounds and their experiences are different."
Penyelesaian konflik di sekolah adalah menjadi tugas kepala sekolah sebagai manajer. Hal ini dijelaskan oleh Folger, et al., (1977) yang menyatakan "School' administrators are managers and they should be able to manage conflict effectively rather than suppress or avoid them" (Akinnubi, et al., 2012: 170).

Kewajiban kepala sekolah untuk dapat menyelesaikan dan mengatasi konflik di sekolah yang dipimpinnya merupakan salah satu indikator dari kompetensi kewirausahaan yang harus dimiliki oleh kepala sekolah. Indikator tersebut adalah berupa mampu menciptakan budaya dan iklim kerja yang kondusif bagi pembelajaran siswa.

Terciptanya iklim kerja yang kondusif akan menjadi pendorong bagi peningkatan kinerja warga sekolah. Hal ini ditegaskan oleh Ubben dan Hughes yang menyatakan bahwa "principals could create a school climate that improves the productivity of both staff and students and that the leadership style of the principal can foster or restrict teacher effectiveness" (Macneil, Prater, dan Busch, 2012: 77). Berdasarkan pandangan tersebut, dapat disimpulkan bahwa peranan kepala sekolah dalam penciptaan iklim sekolah sangat penting.

Mengacu pada latar belakang permasalahan tersebut di atas, penelitian ini bertujuan untuk mendeskripsikan: 1) sumbersumber dan jenis konflik sekolah paskaregrouping; 2) pengelolaan konflik sekolah paska-regrouping; dan 3) faktor pendukung dan penghambat dalam pengelolaan konflik paska regrouping di SD Negeri Pucangsawit Surakarta.

\section{Metode}

Penelitian kualitatif ini menggunakan pendekatan etnografi dengan objek penelitian berupa pengelolaan konflik paska regrouping sekolah di SD Negeri Pucangsawit Surakarta. Desain naturalistik, menurut Sutama (2012: 68-70) berangkat dari lima proposisi dasar. Kelima proposisi tersebut meliputi: 1) realitas kehidupan adalah bersifat kompleks 
dan di dalam realitas tersebut terdapat sistem yang mendasarinya; 2) interaksi yang ada di dalam suatu sistem bersifat indeterminatif, kausalitas bersifat interdependen, dan pengenalan bersifat perspektif; 3) keterkaitan pada konteks menjadikan sesuatu bersifat kompleks, heterarkhis, holografis, dan morfologis; 4) bahwa pembentukan terjadi secara interdependen dan serentak; dan 5) kepentingan atau nilai memberikan perspektif pengetahuan.

Teknik pengumpulan data menggunakan teknik wawancara mendalam, observasi, dan dokumen (Sutopo, 2006: 44). Teknik observasi dilakukan dengan mengunjungi lokasi penelitian. Selain observasi, teknik lain yang digunakan adalah melalui wawancara mendalam dan analisis dokumen.

Pemilihan rancangan analisis untuk penelitian dengan pendekatan kualitatif didasarkan pada tiga komponen utama (Sutopo, 2006: 112). Ketiga komponen pokok tersebut meliputi reduksi data (data reduction), penyajian data (data display), dan penarikan kesimpulan (verification).

\section{Hasil dan Pembahasan}

\section{Sumber-sumber dan Jenis konflik sekolah regrouping di SD Negeri Pucangsawit Surakarta}

Hasil penelitian menunjukkan bahwa pengelolaan sumber-sumber konflik yang terjadi di SD Negeri Pucangsawit Kecamatan Jebres Kota Surakarta dapat diklasifikasi ke dalam 2 jenis sumber, yaitu dari guru dan orang tua siswa. Sumber konflik yang berasal dari guru disebabkan karena persaingan yang sudah berlangsung sejak lama jauh sebelum dilakukan regrouping dan ego sektoral. Adapun sumber yang berasal dari orang tua siswa lebih bersifat ego sektoral yang muncul sejak awal dilakukan regrouping.

Sumber konflik yang berasal dari guru sebagai akibat dari adanya persaingan tidak begitu jelas faktor yang menjadi penyebabnya. Persaingan justru nampak dalam hal peningkatan prestasi baik akademis maupun non akademis. Prestasi sekolah di SD Negeri Kentingan No. 79 Surakarta secara akademik maupun non akademik lebih baik dibandingkan prestasi di SD Negeri Pucangsawit No. 119 Surakarta. Hal ini karena adanya dukungan sumber daya manusia di SD Negeri Kentingan No. 79 Surakarta yang didukung dengan sumberdaya manusia berupa banyaknya tenaga guru Wiyata Bhakti (WB) yang dapat diberdayakan untuk mendukung kegiatan sekolah. Sementara, di sisi lain, sumberdaya manusia di SD Negeri Pucangsawit No. 119 Surakarta sebagian besar diisi oleh guru-guru senior dengan usia menjelang pensiun sehingga kurang bergairah untuk mengadakan berbagai kegiatan di luar tugas pokok mengajar sebagai guru.

Sumber konflik yang berasal dari guru berupa ego sektoral adalah berkaitan dengan penamaan sekolah baru paska-regrouping. Guru-guru dari eks SD Negeri Kentingan No. 79 Surakarta berharap bahwa nama sekolah baru setelah dilakukan penggabungan adalah SD Negeri Kentingan. Hal ini dilandasi adanya alasan bahwa SD Negeri Kentingan lebih dikenal masyarakat, bahwa bangunan sekolah eks SD Negeri Kentingan juga relatif lebih bagus, serta mempunyai prestasi akademik dan non akademik yang lebih baik dibandingkan dengan SD Negeri Pucangsawit No. 119 Surakarta.

Adapun guru-guru dari eks SD Negeri Pucangsawit No. 119 Surakarta berharap bahwa nama sekolah paska-regrouping adalah SD Negeri Pucangsawit Surakarta. Hal ini dilandasi alasan bahwa sekolah tersebut mempunyai letak geografis di wilayah administrasi Kalurahan Pucangsawit, Kecamatan Jebres Kota Surakarta.

Sumber konflik berikutnya adalah sumber konflik yang berasal dari orang tua siswa. Konflik utama disebabkan karena kuatnya ego sektoral dari masing-masing orang tua siswa, baik orang tua siswa dari eks SD Negeri Kentingan No. 79 Surakarta maupun SD Negeri Pucangsawit No. 119 Surakarta.

Orang tua siswa dari eks SD Negeri Kentingan No. 79 Surakarta mengharapkan 
bahwa nama sekolah baru paska-regrouping adalah SD Negeri Kentingan Surakarta. Hal ini didasarkan pada adanya alasan bahwa: 1) SD Negeri Kentingan lebih dikenal masyarakat; 2) SD Negeri Kentingan berdiri lebih awal dibandingkan SD Negeri Pucangsawit; 3) SD Negeri Kentingan lebih berprestasi; dan 4) Mereka dahulu menyekolahkan putra-putri mereka di SD Negeri Kentingan, bukannya SD Negeri Pucangsawit.

Adapun Orang tua siswa dari eks SD Negeri Pucangsawit No. 119 Surakarta mengharapkan bahwa nama sekolah baru paska-regrouping adalah SD Negeri Pucangsawit Surakarta. Hal ini didasarkan pada adanya alasan bahwa: 1) lokasi sekolah berada di wilayah administratif Kalurahan Pucangsawit; dan 2) Mereka dahulu menyekolahkan putra-putri mereka di SD Negeri Pucangsawit, bukannya SD Negeri Kentingan.

Jenis konflik yang terjadi meliputi konflik antar-individu guru dari kedua sekolah yang digabung, konflik penamaan sekolah, konflik terkait dengan tugas profesional dan administrasi kepegawaian guru, konflik terkait administrasi kesiswaan.

Temuan bahwa munculnya konflik sekolah akibat regrouping dilandasi adanya perebutan kepentingan. Temuan tersebut didukung hasil penelitian yang dilakukan oleh Ghaffar (2013) dengan judul "Conflict in Schools: Its Causes and Management Strategies". Penelitian yang dilakukan Ghaffar bertujuan untuk mengeksplorasi sifat-sifat konflik yang terjadi di sekolah, penyebab terjadinya konflik, dan teknikteknik yang dilakukan untuk penyelesaiannya. Penelitian ini merupakan studi kepustakaan. Hasil penelitian menyimpulkan bahwa sifat-sifat konflik yang terjadi di sekolah mencakup konflik yang terjadi antar individu dan konflik antara individu dengan lembaga. Faktor yang menjadi penyebab konflik antara lain meliputi: 1) terbatasnya sumber daya; 2) aktivitas pekerjaan yang saling interdependen; 3) diferensiasi aktivitas pekerjaan; 4) permasalahan komunikasi; 5) perbedaan persepsi; dan 6) lingkungan organisasi. Adapun strategi manajemen konflik yang dilakukan merujuk pada pandangan Thomas, yang menawarkan delapan strategi manajemen, yaitu: (1) Citizens advisories (2) Confrontation sessions (3) Sensitivity training; (4) Process involvement (5) Educational pluralism (6) Volunteerism (7) Cooperative studies (8) Failure.

\section{Pengelolaan konflik sekolah regrouping di SD Negeri Pucangsawit Surakarta}

Pengelolaan jenis-jenis konflik di sekolah paska-regrouping di SD Negeri Pucangsawit Surakarta didasarkan pada empat aspek pengelolaan, yaitu perencanaan, pengorganisasian, pelaksanaan, dan pengendalian.

Langkah yang dilakukan dalam penanganan konflik di sekolah paskaregrouping di SD Negeri Pucangsawit Surakarta pada tahap perencanaan adalah melakukan identifikasi jenis-jenis konflik dan sumbernya. Setelah permasalahan teridentifikasi, langkah berikutnya adalah menyusun strategi penanganan konflik yang akan dilakukan.

Hasil penelitian menunjukkan bahwa pengelolaan jenis-jenis konflik sekolah regrouping di SD Negeri Pucangsawit No. 119 Surakarta dilakukan melalui perencanaan, pengorganisasian, pelaksanaan, dan pengendalian. Keempat aspek tersebut dapat dijelaskan sebagai berikut.

Perencanaan adalah melakukan identifikasi jenis-jenis konflik dan sumbernya. Setelah permasalahan teridentifikasi, langkah berikutnya adalah menyusun strategi penanganan konflik yang akan dilakukan. Pengorganisasian penanganan konflik sekolah paska-regrouping di SD Negeri Pucangsawit No. 119 Surakarta dilakukan menurut kapasitas dan tanggungjawab para pihak yang berkepentingan. Untuk konflik yang masih menjadi tanggungjawab kepala sekolah akan ditangani oleh kepala sekolah sebagai pimpinan tertinggi di tingkat satuan 
pendidikan. Adapun untuk konflik yang sudah berada di luar kewenangan kepala sekolah tentu saja pihak dinas yang akan menananganinya.

Adanya perencanaan dan pengorganisasian sumber konflik dalam Pelaksanaan pengelolaan konflik paskaregrouping di SD Negeri Pucangsawit No. 119 Surakarta mengindikasikan bahwa kepala sekolah memiliki kompetensi sesuai kapasitasnya sebagai kepala sekolah. Temuan ini didukung hasil penelitian yang dilakukan oleh Condon dan Clifford (2012) dalam laporannya yang berjudul "Measuring Principals Performance: How rigorous are commonly used performance assessment instruments?" mengkaji tentang penggunaan standar baru untuk mengukur kinerja kepala sekolah. Standar pengukuran yang digunakan mencakup 6 ranah. Keenam ranah tersebut antara lain meliputi: 1) mempunyai visi pembelajaran yang luas; 2) kemampuan mengembangkan budaya sekolah dan program pengajaran yang kondusif untuk belajar siswa maupun perkembangan profesional guru; 3) kemampuan melaksanakan manajemen organisasi yang efektif; 4) kemampuan bekerjasama dengan pihak lain dan memobilisasi sumberdaya masyarakat; 5) mempunyai integritas; dan 6) mampu memahami dan merespon terhadap konteks sosial, legal, budaya, dan politik. Hasil penelitian menyimpulkan bahwa instrumen yang selama ini digunakan untuk mengukur kinerja kepala sekolah perlu dikaji ulang dan disesuaikan dengan konteks yang ada .

Pelaksanaan pengelolaan konflik paskaregrouping di SD Negeri Pucangsawit No. 119 Surakarta dilakukan sesuai dengan sumber dan jenis konflik yang teridentifikasi. Penanganan masalah konflik yang berkaitan dengan nama sekolah hasil regrouping sudah menjadi kewenangan pemerintah. Hal ini sesuai dengan SK Regrouping yang diterbitkan oleh Walikota Surakarta yang menetapkan bahwa nama sekolah hasil penggabungan adalah SD Negeri Pucangsawit No. 119 Surakarta.
Penanganan konflik yang berkaitan dengan administrasi guru dan kesiswaan sebagian menjadi tanggungjawab dinas dan sebagian menjadi tanggungjawab sekolah. Hal yang menjadi tanggungjawab dinas adalah masalah administrasi guru dan administrasi kesiswaan bagi siswa-siswa alumni eks SD Negeri Kentingan No. 79 Surakarta. Masalah kesiswaan yang ditangani oleh kepala sekolah di SD Negeri Pucangsawit No. 119 Surakarta adalah terbatas pada siswa yang masih bersekolah saat proses regrouping berlangsung. Siswa dari eks SD Negeri Kentingan No. 79 Surakarta dimutasi ke SD Negeri Pucangsawit No. 119 Surakarta dan memperoleh NIS baru sesuai nomor urut yang berlaku di SD Negeri Pucangsawit No. 119 Surakarta.

Adapun pengelolaan administrasi guru yang menjadi tanggungjawab kepala SD Negeri Pucangsawit No. 119 Surakarta adalah setelah dilakukan proses mutasi oleh BKD dan dilimpahkan ke SD Negeri Pucangsawit No. 119 Surakarta dari SD Negeri Kentingan No. 79 Surakarta. Penanganan permasalahan yang terkait dengan jumlah guru yang belum ideal dilakukan dengan cara mutasi, promosi dan pembagian tugas. Mutasi dilakukan bagi guru CPNS yang diangkat menjadi PNS. Promosi dilakukan dengan mendorong guru senior untuk mengikuti seleksi calon kepala sekolah. Adapun pembagian tugas dilakukan bagi guru Wiyata Bhakti.

Pelaksanaan penanganan konflik yang berkaitan dengan prestasi sekolah dilakukan dengan menerapkan persaingan yang adil dan positif (fair and positive competition). Untuk siswa dilakukan seleksi secara adil dalam memilih siswa berprestasi, sedangkan untuk orang tua dilakukan lomba menghias taman untuk menumbuhkan adanya rasa memiliki pada orang tua siswa.

Temuan bahwa penanganan konflik dilakukan dengan cara memberdayakan baik melalui mutasi, promosi, dan penugasan menunjukkan bahwa kepala sekolah mampu menunjukkan kepemimpinan sebagai 
pencipta iklim kerja yang kondusif. Temuan ini didukung hasil penelitian yang dilakukan oleh Dwiningrum dan Widiowati (2014) dengan judul "School Resiliency and Social Capital of Regrouping Policy after Merapi Eruption in the Special District of Yogyakarta of Indonesia (A Case Study at SD Umbulharjo 2, Sleman, Special District of Yogyakarta.

Evaluasi penanganan konflik paska regrouping di SD Negeri Pucangsawit No. 119 Surakarta dilakukan oleh dinas pendidikan melalui UPTD Dikpora Kecamatan Jebres dan kepala sekolah hanya berwenang melaksanakan tugas sesuai kewenangannya. Sekolah hasil regrouping diproyeksikan hanya untuk membelajarkan siswa dalam 6 rombongan belajar pada tahun 2018 .

Penanganan konflik paska regrouping di SD Negeri Pucangsawit No. 119 Surakarta yang dilakukan kepala sekolah melalui kepemimpinannya dengan menerapkan kompromi dan negosiasi menunjukkan bahwa penyelesaian konflik tergantung pada kemampuan kepala sekolah sebagai penanggunjawab di sekolah tersebut. Adanya penyelesaian yang baik mengindikasikan bahwa kepala sekolah mampu menciptakan iklim sekolah yang baik.

Temuan tersebut didukung hasil penelitian yang dilakukan oleh Akinnubi, Oyeniran, Fashiku, dan Durosaro (2012) dalam penelitiannya yang berjudul "Principal's Personal Characteristics and Conflict Management in Kwara State Secondary Schools, Nigeria". Penelitian yang dilakukan Akinnubi, et al., bertujuan untuk mengkaji pengaruh karakteristik kepribadian kepala sekolah terhadap manajemen konflik di sekolah menengah negeri di Nigeria. Jenis penelitian merupakan penelitian survai deskriptif dengan desain ex post facto. Hasil penelitian menyimpulkan bahwa terdapat hubungan yang signifikan antara karakteristik kepribadian kepala sekolah dengan manajemen konflik. Hasil tersebut mengimplikasikan bahwa dalam penyelesaian konflik yang terjadi di sekolah, kepala sekolah harus memahami penyebab konflik terlebih dahulu sebelum menggunakan strategi yang tepat dalam menyelesaikan konflik berdasarkan karakteristik kepribadian yang dimilikinya.

\section{Faktor pendukung dan penghambat dalam penanganan konflik pasca- regrouping di SD Negeri Pucangsawit Kota Surakarta}

Faktor pendukung dalam penanganan konflik paska regrouping di SD Negeri Pucangsawit Surakarta adalah adanya dukungan pemerintah dan kesadaran warga sekolah. Hal ini dijelaskan oleh kepala SD Negeri Pucangsawit Surakarta yang menjelaskan bahwa dukungan yang diberikan pemerintah melalui dinas adalah adanya peningkatan sarana dan prasarana sekolah dan dukungan administrasi baik kesiswaan maupun guru.

Adapun faktor yang menjadi penghambat dalam penanganan konflik paska regrouping di SD Negeri Pucangsawit Surakarta adalah adanya ego sektoral yang melekat pada guru dan orang tua siswa di kedua sekolah yang diregroup.

Temuan tersebut didukung oleh hasil penelitian yang dilakukan Siti Dwiningrum dan Widiowati (2014) dengan judul "School Resiliency and Social Capital of Regrouping Policy after Merapi Eruption in the Special District of Yogyakarta of Indonesia (A Case Study at SD Umbulharjo 2, Sleman, Special District of Yogyakarta)". Hasil penelitian menyimpulkan bahwa: regrouping harus mampu memelihara keberlanjutan pendidikan bagi siswa dan keberlanjutan karir tenaga pendidiknya.

\section{Penutup}

Sumber-sumber konflik yang terjadi di SD Negeri Pucangsawit Kecamatan Jebres Kota Surakarta dapat diklasifikasi ke dalam 2 jenis sumber, yaitu dari guru dan orang tua siswa. Sumber konflik yang berasal dari guru disebabkan karena persaingan yang sudah berlangsung sejak lama jauh sebelum dilakukan regrouping dan ego sektoral. 
Adapun sumber yang berasal dari orang tua siswa lebih bersifat ego sektoral yang muncul sejak awal dilakukan regrouping. Jenis konflik yang terjadi meliputi konflik antar-individu guru dari kedua sekolah yang digabung, konflik penamaan sekolah, konflik terkait dengan tugas profesional dan administrasi kepegawaian guru, konflik terkait administrasi kesiswaan.

Sumber konflik yang berasal dari guru berupa ego sektoral adalah berkaitan dengan penamaan sekolah baru paska-regrouping. Sumber konflik berikutnya adalah sumber konflik yang berasal dari orang tua siswa. Konflik utama disebabkan karena kuatnya ego sektoral dari masing-masing orang tua siswa, baik orang tua siswa dari eks SD Negeri Kentingan No. 79 Surakarta maupun SD Negeri Pucangsawit No. 119 Surakarta.

Pengelolaan konflik sekolah regrouping diSD Negeri PucangsawitSurakarta dilakukan melalui perencanaan, pengorganisasian, pelaksanaan, dan pengendalian. Perencanaan adalah melakukan identifikasi jenis-jenis konflik dan sumbernya. Setelah permasalahan teridentifikasi, langkah berikutnya adalah menyusun strategi penanganan konflik yang akan dilakukan.

Pengorganisasian penanganan konflik sekolah paska-regrouping di SD Negeri Pucangsawit Surakarta dilakukan menurut kapasitas dan tanggungjawab para pihak yang berkepentingan. Untuk konflik yang masih menjadi tanggungjawab kepala sekolah akan ditangani oleh kepala sekolah sebagai pimpinan tertinggi di tingkat satuan pendidikan. Adapun untuk konflik yang sudah berada di luar kewenangan kepala sekolah tentu saja pihak dinas yang akan menananganinya.

Pelaksanaan pengelolaan konflik paskaregrouping di SD Negeri Pucangsawit Surakarta dilakukan sesuai dengan sumber dan jenis konflik yang teridentifikasi. Penanganan masalah konflik yang berkaitan dengan nama sekolah hasil regrouping sudah menjadi kewenangan pemerintah. Hal ini sesuai dengan SK Regrouping yang diterbitkan oleh Walikota Surakarta yang menetapkan bahwa nama sekolah hasil penggabungan adalah SD Negeri Pucangsawit Surakarta.

Penanganan konflik yang berkaitan dengan administrasi guru dan kesiswaan sebagian menjadi tanggungjawab dinas dan sebagian menjadi tanggungjawab sekolah. Hal yang menjadi tanggungjawab dinas adalah masalah administrasi guru dan administrasi kesiswaan bagi siswa-siswa alumni eks SD Negeri Kentingan No. 79 Surakarta. Masalah kesiswaan yang ditangani oleh kepala sekolah di SD Negeri Pucangsawit No. 119 Surakarta adalah terbatas pada siswa yang masih bersekolah saat proses regrouping berlangsung. Siswa dari eks SD Negeri Kentingan No. 79 Surakarta dimutasi ke SD Negeri Pucangsawit No. 119 Surakarta dan memperoleh NIS baru sesuai nomor urut yang berlaku di SD Negeri Pucangsawit No. 119 Surakarta.

Pengelolaan administrasi guru yang menjadi tanggungjawab kepala SD Negeri Pucangsawit No. 119 Surakarta adalah setelah dilakukan proses mutasi oleh BKD dan dilimpahkan ke SD Negeri Pucangsawit No. 119 Surakarta dari SD Negeri Kentingan No. 79 Surakarta. Penanganan permasalahan yang terkait dengan jumlah guru yang belum ideal dilakukan dengan cara mutasi, promosi dan pembagian tugas. Mutasi dilakukan bagi guru CPNS yang diangkat menjadi PNS. Promosi dilakukan dengan mendorong guru senior untuk mengikuti seleksi calon kepala sekolah. Adapun pembagian tugas dilakukan bagi guru Wiyata Bhakti.

Pelaksanaan penanganan konflik yang berkaitan dengan prestasi sekolah dilakukan dengan menerapkan persaingan yang adil dan positif (fair and positive competition). Untuk siswa dilakukan seleksi secara adil dalam memilih siswa berprestasi, sedangkan untuk orang tua dilakukan lomba menghias taman untuk menumbuhkan adanya rasa memiliki pada orang tua siswa. 
Evaluasi penanganan konflik paska regrouping di SD Negeri Pucangsawit Surakarta dilakukan oleh dinas pendidikan melalui UPTD Dikpora Kecamatan Jebres dan kepala sekolah hanya berwenang melaksanakan tugas sesuai kewenangannya. Sekolah hasil regrouping diproyeksikan hanya untuk membelajarkan siswa dalam 6 rombongan belajar pada tahun 2018 .

Faktor pendukung dalam penanganan konflik paska regrouping di SD Negeri Pucangsawit Surakarta adalah adanya dukungan pemerintah dan kesadaran warga sekolah. Faktor penghambat dalam penanganan konflik paska regrouping di SD Negeri Pucangsawit Surakarta adalah berupa adanya ego sektoral yang melekat pada guru dan orang tua siswa di kedua sekolah yang diregroup.
Berdasarkan hasil penelitian ini selanjutnya dapat dikemukakan implikasi hasil penelitian baik secara teoretis maupun secara praktis sebagai berikut: 1) Regrouping sekolah yang bertujuan meningkatkan kualitas pendidikan dengan cara meningkatkan efektivitas dan efisiensi pengelolaan pendidikan harus memperhatikan aspekaspek sosial yang terjadi paska-regrouping; 2) Penanganan konflik sekolah paskaregrouping akan lebih baik bila dilakukan dengan strategi memberdayakan; dan 3) Faktor pendukung dalam penanganan konflik paska regrouping harus diberdayakan secara optimal untuk meminimalisir faktor penghambat, sehingga penanganan konflik paska-regrouping dapat memuaskan semua pihak yang berkepentingan.

\section{Daftar Pustaka}

Akinnubi, O. P., S. Oyeniran., C. O. Fashiku., and I. A. Durosaro. "Principal's Personal Characteristics and Conflict Management in Kwara State Secondary Schools, Nigeria". International Journal of Academic Research in Business and Social Sciences, June 2012, Vol. 2, No. 6, pp: 167-174, http://www.proquest.umi.com diakses pada 10 Januari 2015.

Barrett, Catherine., and Robert Breyer. 2014. "The Influence of Effective Leadership on Teaching and Learning," Journal of Research Initiatives: Vol. 1: Iss. 2, Article 3., http:// www.proquest.umi.com diakses pada 10 Januari 2015.

Bogdan, Rober C., and Sari Knopp Biklen. 2005. Qualitative Research for Education. Boston: Allyn and Bacon.

Condon, Cristopher and Matthew Clifford,. 2012. "Measuring Principals Performance: How rigorous are commonly used performance assessment instruments?". Journal of Educational Management. Sage Publication Vol. 8 No.1, 2012, pp: 1- 14, http://www. proquest.umi.com diakses pada 10 Juli 2014.

Dwiningrum, Siti Irene Astuti dan Rani Widiowati. 2014. "School Resiliency and Social Capital of Regrouping Policy after Merapi Eruption in the Special District of Yogyakarta of Indonesia (A Case Study at SD Umbulharjo 2, Sleman, Special District of Yogyakarta)". International Journal of Asian Social Science Vol. 4 No. 4, 2014, pp: 510-525, http:// www.proquest.umi.com diakses pada 10 Januari 2015.

Elmore, R., \& Burney, D. 2004. Leadership and learning: Principal recruitment, induction, and instructional leadership in Community School District \#2, New York City. Pittsburgh, PA: University of Pittsburgh, Learning and Research Development Center, http://www. proquest.umi.com diakses pada 10 Juli 2012.

Ghaffar, Abdul. 2013. "Conflict in Schools: Its Causes and Management Strategies" Journal of Managerial Sciences Vol. 111 No. 11, pp: 212 - 227, http://www.proquest.umi.com diakses pada 10 Januari 2015. 
Goddard, Yvonne L., Robert Miller., Ross Larson., Roger Goddard. "Connecting Principal Leadership, Teacher Collaboration, and Student Achievement". Journal of Education Leadership Research Center (ELRC), Vol. 1 No. 1, 2014, pp: 1-32., http://www.proquest. umi.com diakses pada 10 Januari 2015

Goertz, Margareth, Suzanna Loeb, and Jim Wyckoff. 2010. Recruiting, Evaluating and Retaining Teachers: The Children First Strategy to Improve New York City's Teachers. Journal of Education Reform Vol. 1 No. 1, 2010, http://www.proquest.umi.com, diakses pada 10 Juli 2014.

Howley, Craig., Jerry Johnson., Jennifer Petrie. 2011. "Consolidation of Schools and Districts: What the Research Says and What It Means" National Education Policy Center (NEPC), Vol. 12, No. 1, pp: 73-84, http://www.proquest.umi.com, diakses pada 15 Januari 2015.

Kiemas Rizka (2004). Manajemen Sarana dan Prasarana Pendidikan Sekolah Dasar Negeri yang Diregrouping se Kecamatan Wates, Kabupaten Kulon Progo. FIP UNY.

Macneil, Angus J., Doris L. Prater., and Steve Busch. 2012. "The effects of school culture and climate on student achievement" International Journal Leadership in Education, Vol. 12, No. 1, pp: 73-84, http://www.proquest.umi.com, diakses pada 15 Januari 2015.

Msila, Vuyisile. 2012. "Conflict Management and School Leadership" Journal of Communication Vol. 3 No. 1, 2012, pp: 25 - 34, http://www.proquest.umi.com diakses pada 10 Januari 2015.

Mulford, Bill. 2003. "School Leaders: Changing Roles and Impact on Teacher and School Effectiveness". Education and Training Policy Division, OECD, http://www.proquest. umi.com diakses pada 10 Juli 2014.

Sudiyono. 2007. Dari Formulasi ke Implementasi Kebijakan Pendidikan. FIP UNY.

Sutama. 2012. Metode Penelitian Pendidikan: Kuantitatif, Kualitatif, PTK, R\&D. Surakarta: Fairuz Media.

Sutopo, H. 2006. Metode Penelitian Kualitatif. Surakarta: UNS Press. 